\title{
Comparison of a diurnal vs steady-state ozone exposure profile on growth and yield of oilseed rape (Brassica napus L.) in open-top chambers in the Yangtze Delta, China
}

\author{
Xiaoke Wang ${ }^{\mathrm{a}, *}$, Qiwei Zheng ${ }^{\mathrm{a}}$, Zhaozhong Feng ${ }^{\mathrm{a}}$, Juqing Xie ${ }^{\mathrm{b}}$, Zongwei Feng ${ }^{\mathrm{a}}$, \\ Zhiyun Ouyang ${ }^{\text {a }}$, William J. Manning ${ }^{\mathrm{c}}$ \\ a State Key Laboratory of Urban and Regional Ecology, Research Center for Eco-Environmental Sciences, Chinese Academy of Sciences, \\ Shuangqinglu 18, Beijing 100085, China \\ ${ }^{\mathrm{b}}$ Northwestern Sci-Tech University of Agriculture and Forestry, Yangling, Shaanxi 712100, China \\ ${ }^{\mathrm{c}}$ Department of Plant, Soil and Insect Sciences, University of Massachusetts, Amherst, MA 01003-9320, USA
}

Received 7 July 2007; received in revised form 16 January 2008; accepted 20 January 2008

Diurnal variation of $\mathrm{O}_{3}$ concentration should be considered when designing $\mathrm{O}_{3}$ exposure experiment.

\begin{abstract}
Most available exposure-response relationships for assessing crop loss due to elevated ozone $\left(\mathrm{O}_{3}\right)$ have been established using data from chamber and open-top chamber experiments, using a simulated constant $\mathrm{O}_{3}$ concentration exposure (square wave), which is not consistent with the diurnal variation of $\mathrm{O}_{3}$ concentration that occurs in nature. We investigated the response of oilseed rape (Brassica napus L.) to $\mathrm{O}_{3}$ as affected by two exposure regimes: one with a diurnal variation (CF100D) and another with a constant concentration (CF100). Although the two exposure regimes have the same mean $\mathrm{O}_{3}$ concentration and accumulated $\mathrm{O}_{3}$ concentration above 40 ppb (AOT40), our results show that $\mathrm{O}_{3}$ at $\mathrm{CF} 100 \mathrm{D}$ reduced biomass and number of pods/plant more than $\mathrm{O}_{3}$ at CF100. Both $\mathrm{O}_{3}$ exposures resulted in larger seed weights/ 100 pods compared to CF. Numbers of seeds/100 pods were reduced by CF100, while numbers of seeds/100 pods in the CF100D chambers were comparable to those in CF. Our results suggest that chamber experiments that use a constant $\mathrm{O}_{3}$ exposure may underestimate $\mathrm{O}_{3}$ effects on biomass and yields.
\end{abstract}

(C) 2008 Published by Elsevier Ltd.

Keywords: Ozone; Exposure regimes; Oilseed rape; Yield; Biomass

\section{Introduction}

Tropospheric ozone levels are decreasing in Europe and North America (Coyle et al., 2003; Ashmore, 2005), but are increasing and are predicted to continue to rise in Asia, due to increased economic growth and higher emission levels of VOCs and $\mathrm{NO}_{x}$, resulting in higher levels of crop losses (van Aardenne et al., 1999; Aunan et al., 2000; Wang and Mauzerall, 2004; Ashmore et al., 2006; Wang et al., 2005). Tropospheric ozone levels in China have been investigated

\footnotetext{
* Corresponding author. Tel./fax: +861062943822.

E-mail address: wangxk@rcees.ac.cn (X. Wang).
}

and crop losses due to ozone have been determined (Zheng, 2006; Wang et al., 2007a,b). These predictions and results from initial investigations confirm the need to establish exposure-response relationships for tropospheric ozone and crop plants in China.

Open-top chambers (OTCs) have been used in Europe and North America for many years to assess the impact of ambient ozone and elevated ozone exposures on growth and productivity of a wide variety of crops and trees (Heagle, 1989; USEPA, 1996; Colls, 2002). Assessment of ambient ozone exposure usually involves three treatments: CF chambers (charcoal-filtered air to remove most ambient ozone), NF chambers (non-filtered air) and AA plots (non-chamber plots in open 
ambient air). Comparing results from NF to $\mathrm{CF}$ should indicate the effects of ambient ozone. If results from $\mathrm{NF}$ and AA are not in agreement, however, then the NF chamber may have had an effect of its own on plant growth and yield (Colls, 2002). OTCs have been used quite successfully to establish exposure-response relationships where ozone levels above ambient have been added to either NF or CF. Results from these investigations can be used to predict future effects of rising ozone levels on crop losses.

Many previous investigations on ozone effects on crop losses have used some type of an exposure chamber and a steadystate fixed ozone exposure profile or a square wave exposure regime (Hogsett et al., 1985). Ozone formation and destruction in the troposphere, however, follow a diurnal pattern. If precursors are produced locally, peak ozone levels usually occur around noon. If precursors travel distances, then peaks usually occur in late afternoon (Colls, 2002). Several investigators have developed exposure regimes where ozone is added at an elevated level in mid to late afternoon. Using closed greenhouse exposure chambers, Musselman et al. (1994) concluded that peak ozone concentrations were important in reducing growth and yield of bean (Phaseolus vulgaris L.). Oksanen and Holopainen (2001), working with birch (Betula pendula Roth.) clones, reported that high ozone peaks caused visible injury, but that cumulative exposures caused growth reductions. Closed outdoor exposure chambers were used in a series of experiments in Germany. Greatest effects on growth and yield were found at higher rather than intermediate peak levels for alfalfa (Hogsett et al., 1985), spring wheat (Triticum aestivum L.) (Meyer et al., 1997, 2000), bean (P. vulgaris L.) (Musselman et al., 1994), potato (Solanum tuberosum L.) (Köllner and Krause, 2000), birch (B. pendula cv. Roth) (Oksanen and Holopainen, 2001) and rape (Brassica napus L.) (Köllner and Krause, 2003). OTCs have also been used to study the effects of the addition of ozone to ambient levels on growth and yield of crop plants. The effects of adding an elevated concentration of ozone for a few hours per day was compared to steady-state low ozone exposure on growth and yield of spring wheat in Ireland. Additional ozone increased leaf senescence and decreased yield, with the effect increasing as the concentration of the added ozone increased (Finnan et al., 1996a,b, 1998).

Oilseed rape (B. napus L.) is used to produce $32.4 \%$ of the vegetable oil used in China. Since 1950, rape crops in China have increased 10-fold and now constitute $25 \%$ of the world's rape crop (Peng et al., 2006). Adaros et al. (1991) compared steady-state ozone exposure with three levels of added ozone in OTCs and found that yields decreased with increasing ozone levels. Ozone was shown to affect rape flowers and reduce seed set in closed chambers (Bosac et al., 1994). Köllner and Krause (2003), using outdoor closed chambers, found that late day peak ozone exposures reduced rape yield more than steady-state exposure. Elevated ozone exposure in an openfield system reduced rape seed yield (Ollerenshaw et al., 1999). Rape cultivars were also shown to vary in ozone sensitivity and yield responses (Adaros et al., 1991; Bosac et al., 1994; Ollerenshaw et al., 1999).
Oilseed rape is an important crop in China. Ozone sensitivity of Chinese rape cultivars and effects on yield are unknown. We decided to compare a diurnal vs steady-state ozone exposure profile on growth and yield of a common oilseed rape cultivar, using OTCs in the Yangtze Delta region in China.

\section{Materials and methods}

\subsection{Experimental site}

The experimental site is located at the Shuangqiao Farm $\left(31^{\circ} 53^{\prime} \mathrm{N}\right.$, $121^{\circ} 18^{\prime} \mathrm{E}$ ) in Jiaxing City, Zhejiang Province, about $100 \mathrm{~km}$ from Shanghai, China's largest city. This site is in the center of the Yangtze Delta and is one of the most important crop production areas in China. It is influenced by the Asian monsoon climate system, with cold dry winters and warm wet summers. Mean temperature and annual precipitation are $15.5^{\circ} \mathrm{C}$ and $1199 \mathrm{~mm}$, respectively. The prevailing cultivation rotation is wheat-rice or rape-rice.

\subsection{Open-top chambers}

OTCs ( $2.2 \mathrm{~m}$ high and $2 \mathrm{~m}$ in diameter) consisting of an octagonal aluminum frame covered by transparent film were used for exposure studies. They have an improved innovative ozone distribution system. A rotatable transparent pipe with many small holes (diameter of $10 \mathrm{~mm}$ at interval of $10 \mathrm{~cm}$ ) releases either charcoal-filtered air (CF) or ozone above the crop canopy. It is driven either by $\mathrm{CF}$ air or ozone $+\mathrm{CF}$ from a centrifugal blower. $\mathrm{O}_{3}$ was generated from pure oxygen by high-voltage electric discharge (Yuyao Shenglete Company, Zhejiang, China). A series of solenoid valves, linked online with a programmable Log Controller (PLC K80S, LG, Korea), were used to control gas meters to provide oxygen based on the established relationship between $\mathrm{O}_{3}$ concentration within OTC and oxygen volume. $\mathrm{O}_{3}$ concentrations within OTCs were monitored by an $\mathrm{O}_{3}$ analyzer (Model $9810 \mathrm{~B}$, Monitor Labs). $\mathrm{O}_{3}$ concentration monitoring has shown that $\mathrm{O}_{3}$ concentrations were uniformly distributed vertically and horizontally within the OTC. A $21 \mathrm{x}$ (L) data logger (Campbell Scientific, Inc) was connected to stored $\mathrm{O}_{3}$ concentration data and to monitor temperature within OTCs using constantan-copper thermocouple. The performance of the OTC has been assessed in field (Zheng et al., 2007).

\subsection{Experimental designs}

There were three treatments: charcoal-filtered air (CF), a constant $\mathrm{O}_{3}$ concentration of $100 \mathrm{ppb}$ for $8 \mathrm{~h}$ (09:00-17:00) (CF100), exposure to $\mathrm{O}_{3}$ with a simulated diurnal variation: $50 \mathrm{ppb}_{3}$ from 09:00-10:00, $100 \mathrm{ppb}_{3}$ from 10:00-12:00, $150 \mathrm{ppb} \mathrm{O}_{3}$ from 12:00-14:00, $100 \mathrm{ppb} \mathrm{O}_{3}$ from 14:00-16:00, and $50 \mathrm{ppb} \mathrm{O}_{3}$ from 16:00-17:00 (CF100D) (Fig. 1). Each treatment had three replicate OTCs layouted randomly. Plants were exposed to $\mathrm{CF}$ or $\mathrm{O}_{3}$ for 39 days, from 23 March to 25 May, except on rainy days.

\subsection{Crop management}

Oilseed rape (B. napus L. cv Huyou 19) was sown on 20 October 2004 and then transplanted into OTCs established in field on 18 November when the seedling was $6-8 \mathrm{~cm}$ height with $6-8$ leaves. The rape was harvested on 26 May. The soil developed from peatland is clay. Generally, wheat or rape have been planted in winter and next spring, and rice in summer and fall. For rape there is no irrigation because of lowland. Fertilizers of $22.5 \mathrm{~kg} \mathrm{~N} / \mathrm{ha}$, $22.5 \mathrm{~kg} \mathrm{P}_{2} \mathrm{O}_{5} /$ ha and $22.5 \mathrm{~kg} \mathrm{~K}_{2} \mathrm{O} /$ ha were applied by hand-burried between plant rows in early spring. Crop practices were adopted according to local agronomic customs so that water, fertilizer, pathogen, insect and weed were not limiting factors. 


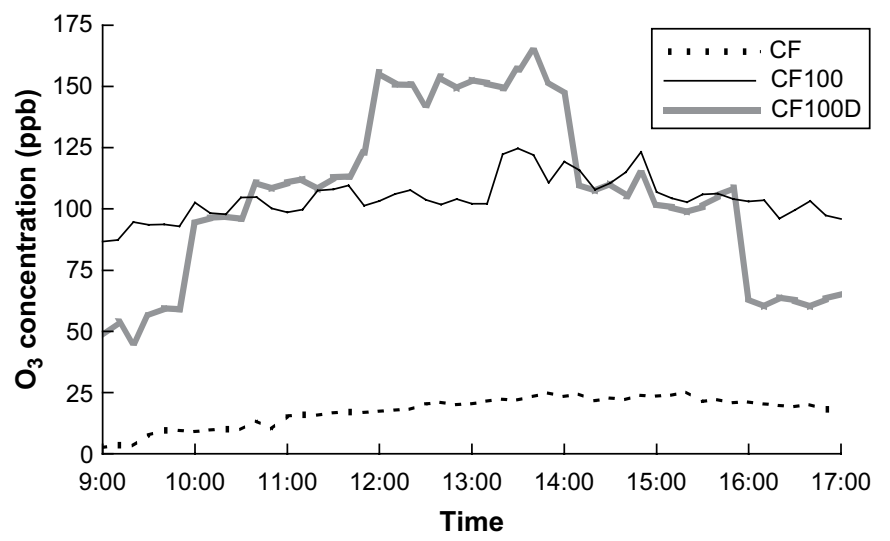

Fig. 1. The diurnal variation of $\mathrm{O}_{3}$ concentration monitoring within OTC for different treatment.

\subsection{Biomass and yield}

On 25 May 2004 when the oilseed rape was ripe, 15 plants were sampled from each OTC for biomass and yield determination. Main rachis, branch and root biomass were weighted after drying at $85^{\circ} \mathrm{C}$ for $48 \mathrm{~h}$. The numbers of pod on main rachis and branches were counted and seeds were weighed separately. Seed weight and number of 100 pods were calculated.

\subsection{Statistical analysis}

An analysis of variance (ANOVA) was used to test for mean differences between treatments $(n=3)$. The Fisher's Protected LSD test was used for post hoc examination of treatment differences. The statistics was performed by the statistical package SPSS (SPSS Inc., Chicago, IL, USA).

\section{Results}

\subsection{Ozone exposure}

In the $\mathrm{CF} 100$ and $\mathrm{CF} 100 \mathrm{D}$ treatments, the mean $\mathrm{O}_{3}$ concentration and the accumulative index AOT40 (accumulated hourly $\mathrm{O}_{3}$ concentration above $40 \mathrm{ppb}$ during daylight hours) are identical: $100 \mathrm{ppb}$ and $0.48 \mathrm{ppm} \mathrm{h}$ per day, respectively. In the experimental period, $\mathrm{O}_{3}$ concentrations ranged from 2.4 to $23.9 \mathrm{ppb}$ in $\mathrm{CF}$, from 89.7 to $113.9 \mathrm{ppb}$ in CF100 and from 47.8 to $164.3 \mathrm{ppb}$ in CF100D. Their average concentrations were $15.6 \mathrm{ppb}, 103.6 \mathrm{ppb}$ and $109.2 \mathrm{ppb}$, and AOT40 were $0 \mathrm{ppm} \mathrm{h}, 17.68 \mathrm{ppm} \mathrm{h}$ and $18.76 \mathrm{ppm} \mathrm{h}$ for $\mathrm{CF}, \mathrm{CF} 100$ and CF100D treatments, respectively.

\subsection{Biomass responses}

Both $\mathrm{O}_{3}$ regimes resulted in biomass reduction for rape. Compared with $\mathrm{CF}$, total biomass was reduced by $9.8 \%$ under CF100 exposure and $21.5 \%$ under CF100D exposure, respectively (Fig. 2). The main rachis, branch, root and total biomass under CF100D exposures were lower than that under CF100 exposure. The main rachis was most significantly affected, with a significant difference for CF100D (Fig. 2).

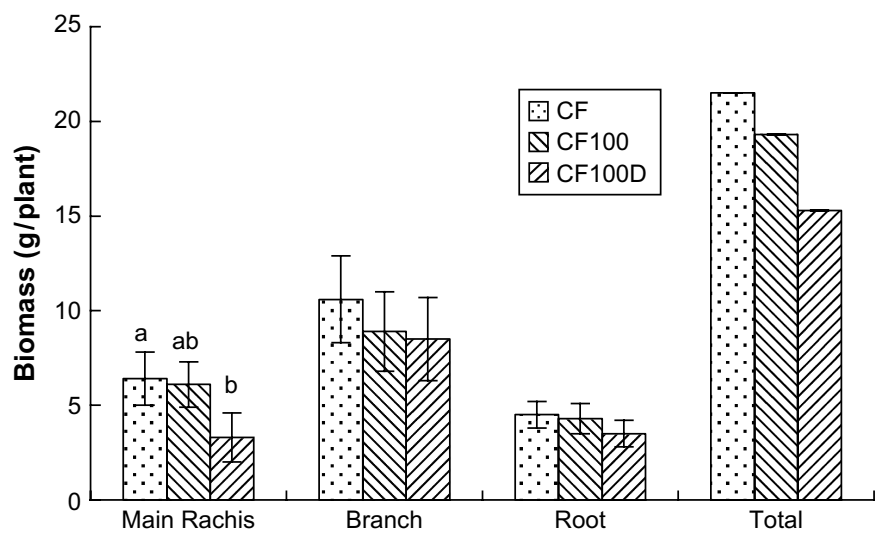

Fig. 2. Biomass of oilseed rape under different $\mathrm{O}_{3}$ exposure regime. Values that have different letter designations are significantly different from each other $(P<0.05)$.

\subsection{Yield responses}

Numbers of pods per plant on primary and secondary branches were decreased for rape exposed to both CF100 and CF100D exposures (Fig. 3). Those reductions were
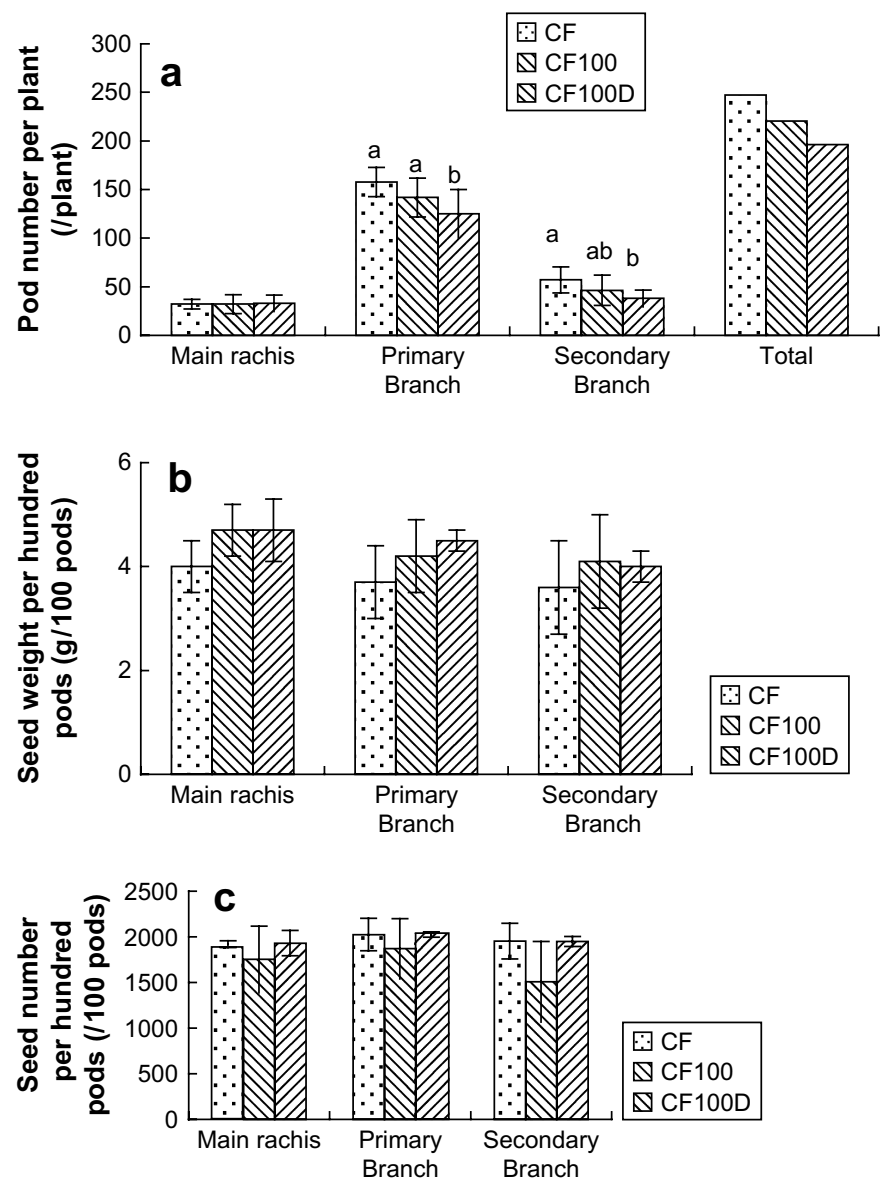

Fig. 3. Pod number and weight of oilseed under different exposure regime. (a) Number of pods per plant, (b) seed weight of one hundred pods, and (c) seed number of one hundred pods. Values that have different letter designations are significantly different from each other $(P<0.05)$. 
significant $(P<0.05)$ for $\mathrm{CF} 100 \mathrm{D}$ exposure but not for $\mathrm{CF} 100$ exposure relative to $\mathrm{CF}$ (Fig. 3). Both $\mathrm{O}_{3}$ exposures resulted in larger seed weights $/ 100$ pods compared to $\mathrm{CF}$. Numbers of seeds $/ 100$ pods were reduced by CF100, while numbers of seeds/100 pods in CF100D chambers were comparable to those in CF. These differences in seed weight and number per 100 pods with increasing $\mathrm{O}_{3}$ concentration were not significant.

\section{Discussion}

Both $\mathrm{O}_{3}$ exposure regimes reduced rape plant biomass, with greater reduction for CF100D. This in turn affected pod production per plant. Reductions in pod numbers by CF100D were significantly different from the CF control, while those caused by CF100 were not. Ollerenshaw et al. (1999) reported that $\mathrm{O}_{3}$ reduced pod numbers for rape in an open-field exposure study. Ozone increased bud abortion and pod abscission in rape plants in chamber $\mathrm{O}_{3}$ fumigation studies (Bosac et al., 1994). Both CF100 and CF100D exposures resulted in larger seed weights per 100 pods than CF. Seed numbers per pod were decreased by CF100, but not by CF100D, which were comparable to $\mathrm{CF}$, but the differences were not significant. Larger seeds may be a compensation mechanism for pod losses due to $\mathrm{O}_{3}$ (Ollerenshaw et al., 1999).

Most of the available data about $\mathrm{O}_{3}$-induced crop losses come from experiments where some type of laboratory, greenhouse, closed, or open-top (OTC) chambers were used to enable an exposure regime for $\mathrm{O}_{3}$ to be established so that comparisons could be made to charcoal-filtered air (CF) as a comparison. All of the exposure regimes used are, by their very nature, artificial and this affects the relevancy of the results that are obtained. Early work was done with constant concentration square wave levels of $\mathrm{O}_{3}$. It was realized that the results obtained related only to the conditions of each experiment. Later work focused on adding $\mathrm{O}_{3}$ to ambient air late in the day to begin to simulate the normal diurnal pattern of $\mathrm{O}_{3}$ in nature. This led to different results. We simulated a more complete and unique diurnal cycle here, by having concentrations' change throughout the day.

Others have devised $\mathrm{O}_{3}$ exposure regimes that focus on high $\mathrm{O}_{3}$ concentrations late in the afternoon. Extensive work in Ireland with $\mathrm{O}_{3}$ and spring wheat (T. aestivum) in OTCs showed that leaf senescence accelerated and yields decreased as $\mathrm{O}_{3}$ additions increased (Finnan et al., 1996a,b, 1998), compared to constant $\mathrm{O}_{3}$ exposure. Working in closed greenhouse chambers in the USA, Musselman et al. (1994) demonstrated significant differences for kidney bean plants $(P$. vulgaris) between $\mathrm{O}_{3}$ exposure profiles, with and without high or peak concentrations, where mean concentration or total exposure was the same. Foliar injury was increased, but pod numbers and biomass were reduced when peak levels were included. Similar results were demonstrated in closed outdoor chambers in Germany for spring wheat (Meyer et al., 1997, 2000), potato (S. tuberosum) (Köllner and Krause, 2000), and rape (B. napus) (Köllner and Krause, 2003). In work with clonal birch (B. pendula) in Finland, however, Oksanen and Holopainen
(2001) achieved different results. High $\mathrm{O}_{3}$ peaks caused visible foliar injury, but only cumulative exposures caused growth reductions. This suggests that results obtained from annual crop plants may not necessarily relate to perennial plants, such as trees.

Using our complete diurnal exposure regime, we have been able to demonstrate that it produced more relevant results than using a single constant $\mathrm{O}_{3}$ exposure regime. Greater yield losses were identified with CF100D than with CF100. Plant can defense to $\mathrm{O}_{3}$ damage by restricting entry of $\mathrm{O}_{3}$ into leaf tissue and detoxifying $\mathrm{O}_{3}$ once it enters leaf, but this defense would be limited under higher $\mathrm{O}_{3}$ concentration (Musselman et al., 2006). This result also suggests that additional research with other plants, especially trees is warranted. The use of sequential sampling, or growth analysis, during such experiments would also be useful in determining when and how changes occur (Manning, 2005).

It is also realized that the diurnal exposure regime used is also a constant exposure treatment, in that it is the same every day, making it difficult to relate the results to ambient conditions in the Yangtze Delta. An alternative would be to grow plants in open fields and to treat half of them with the ozone injury-supressant ethylenediurea (EDU), compare results with non-treated plants and relate them to monitored ambient $\mathrm{O}_{3}$, considering the impacts of periodic high $\mathrm{O}_{3}$ concentrations vs daily lower concentrations. This approach has been successful in China and elsewhere (Manning et al., 2003; Tiwari et al., 2005; Wang et al., 2007a,b).

\section{Conclusions}

By using a complete diurnal $\mathrm{O}_{3}$ exposure regime in OTCs, we have been able to demonstrate that it caused more reduction in biomass production and pod and seed yields of rape than a steady-state single $\mathrm{O}_{3}$ concentration, even though the two exposure regimes have the same mean $\mathrm{O}_{3}$ concentration and the same AOT40 value. This confirms results of others who used partial diurnal exposure regimes.

Our results also indicate that air quality standards for ozone, which rely on mean $\mathrm{O}_{3}$ concentrations or AOT40, would underestimate crop losses caused by $\mathrm{O}_{3}$, as they are based on data from constant, non-diurnal ozone exposures.

Our diurnal exposure regime was useful for detecting different levels of response of rape to $\mathrm{O}_{3}$.It is recognized, however, that this regime is also a steady-state exposure, as it is the same every day. A useful alternative to this limitation would be to work under natural field conditions with natural $\mathrm{O}_{3}$ exposures. A control could be established by treating half of the plants with EDU. We have demonstrated the utility of this approach in China with rice and wheat in the Yangtze Delta.

\section{Acknowledgement}

This research was supported by Ministry of Science and Technology of China under 973 project (no. 2002CB410803) and National Nature Science foundation of China (30670387). 


\section{References}

van Aardenne, J.A., Carmichael, G.R., Levy, H., Streets, D., Hordijk, L., 1999. Anthropogenic $\mathrm{NO}_{x}$ emissions in Asia in the period 1990-2020. Atmospheric Environment 33, 633-646.

Adaros, G., Weigel, H.J., Jager, H.J., 1991. Single and interactive effects of low level of $\mathrm{O}_{3}, \mathrm{SO}_{2}$ and $\mathrm{NO}_{2}$ on the growth and yield of spring rape. Environmental Pollution 72, 269-286.

Ashmore, M.R., 2005. Assessing the future global impacts of ozone on vegetation. Plant, Cell and Environment 28, 949-964.

Ashmore, M., Toet, S., Emberson, L., 2006. Ozone - a significant threat to future world food production? New Phytologist 170, 199-201.

Aunan, K., Berntsen, T.K., Seip, H.M., 2000. Surface ozone in China and its possible impact on agricultural crop yields. Ambio 29, 294-301.

Bosac, C., Roberts, J.A., Black, V.J., Black, C.R., 1994. Impact of $\mathrm{O}_{3}$ and $\mathrm{SO}_{2}$ on reproductive development in oilseed rape (Brassica napus L.). II. Reproductive site losses. New Phytologist 126, 71-79.

Colls, J., 2002. Air Pollution. Spon Press, London.

Coyle, M., Fowler, D., Ashmore, M., 2003. New directions: implications of increasing tropospheric background ozone concentrations for vegetation. Atmospheric Environment 37, 153-154.

Finnan, J.M., Jones, M.B., Burke, J.I., 1996a. A time-concentration study on the effects of ozone on spring wheat (Triticum aestivum L.) 1: effects on yield. Agriculture, Ecosystems and Environment 57, 159-167.

Finnan, J.M., Jones, M.B., Burke, J.I., 1996b. A time-concentration study on the effects of ozone on spring wheat (Triticum aestivum L.) 2: a comparison of indices. Agriculture, Ecosystems and Environment 57, 169-177.

Finnan, J.M., Jones, M.B., Burke, J.I., 1998. A time-concentration study on the effects of ozone on spring wheat (Triticum aestivum L.) 3: effects on leaf area and flag leaf senescence. Agriculture, Ecosystems and Environment $69,27-35$.

Heagle, A.S., 1989. Ozone and crop yield. Annual Review of Phytopathology 27, 397-423.

Hogsett, W.E., Tingey, D.T., Holman, S.R., 1985. A programmable exposure control system for determination of the effects of pollutant exposure regimes on plant growth. Atmospheric Environment 19, 1135-1145.

Köllner, B., Krause, G.H.M., 2000. Changes in carbohydrates, leaf pigments and yield in potatoes induced by different ozone exposure regimes. Agriculture, Ecosystems and Environment 78, 149-158.

Köllner, B., Krause, G.H.M., 2003. Effects of two different ozone exposure regimes on chlorophyll and sucrose content of leaves and yield parameters of sugar beet (Beta vulgaris L.) and rape (Brassica napus L.). Water, Air and Soil Pollution 144, 317-332.

Manning, W.J., Flagler, R.B., Frenkel, M.A., 2003. Assessing plant response to ambient ozone: growth of ozone-sensitive loblolly pine seedlings treated with ethylenediurea or sodium erythorbate. Environmental Pollution 126, 73-81.

Manning, W.J., 2005. Establishing a cause and effect relationship for ambient ozone exposure and tree growth in the forest: progress and an experimental approach. Environmental Pollution 137, 443-453.
Meyer, U., Köllner, B., Willenbrink, J., Krause, G.H.M., 1997. Effects of ozone on agricultural crops in Germany. I. Different ambient ozone exposure regimes affect photosynthesis and assimilate allocation in spring wheat. New Phytologist 136, 645-652.

Meyer, U., Kollner, B., Willenbrink, J., Krause, G.H.M., 2000. Effects of different ozone exposure regimes on photosynthesis, assimilates, and thousand grain weight in spring wheat. Agriculture, Ecosystems and Environment 78, 49-55.

Musselman, R.C., Younglove, T., McCool, M.P., 1994. Response of Phaseolus vulgaris $\mathrm{L}$. to differing ozone regimes having identical total exposure. Atmospheric Environment 28, 2727-2731.

Musselman, R.C., Lefohn, A.S., Massman, W.J., Heath, R.L., 2006. A critical review and analysis of the use of exposure- and flux-based ozone indices for predicting vegetation effects. Atmospheric Environment 40, 1869-1888.

Oksanen, E., Holopainen, T., 2001. Responses of two birch (Betula pendula Roth.) clones to different ozone profiles with similar AOT40 exposure. Atmospheric Environment 35, 5245-5254.

Ollerenshaw, J.H., Lyons, T., Barnes, J.D., 1999. Impacts of ozone on the growth and yield of field-grown winter oilseed rape. Environmental Pollution 104, 53-59.

Peng, K., Qi, C., Lei, H., 2006. Application of grey conjunction theory in decision making for rape production in China. Zhejiang Agricultural Sciences 4, 361-363 (in Chinese).

Tiwari, S., Agrawal, M., Manning, W.J., 2005. Assessing the impact of ambient ozone on growth and productivity of two cultivars of wheat in India using three rates of application of ethylenediurea (EDU). Environmental Pollution 138, 153-160.

USEPA, 1996. Air Quality Criteria for Ozone and Related Photochemical Oxidants. Office of Health and Environmental Assessment, Environmental Criteria and Assessment Office, Research Triangle Park, NC. Report No. EPA-600/p-93/004aF-Cf.

Wang, H.X., Kiang, C.S., Tang, X.Y., Zhou, X.J., Chameides, W.L., 2005. Surface ozone, a likely threat to crops in Yangtze delta of China. Atmospheric Environment 39, 3843-3850.

Wang, X., Mauzerall, D.L., 2004. Characterizing distributions of surface ozone and its impact on grain production in China, Japan and South Korea, 1990 and 2020. Atmospheric Environment 38, 4383-4402.

Wang, X., Manning, W., Feng, Z., Zhu, Y., 2007a. Ground-level ozone in China: distribution and effects on crops. Environmental Pollution 147, 394-400.

Wang, X., Zheng, Q., Yao, F., Chen, Z., Feng, Z., Manning, W.J., 2007b. Assessing the impact of ambient ozone on growth and yield of a rice (Oryza sativa L.) and a wheat (Triticum aestivum L.) cultivar grown in the Yangtze Delta, China, using three rates of application of ethylenediurea (EDU). Environmental Pollution 148, 390-395.

Zheng, Q.W., 2006. Studies on Effect of Elevated Ozone on Typical Crops in Yangtze River Delta, China. Research Center for Eco-Environmental Sciences, Chinese Academy of Sciences (in Chinese).

Zheng, Q., Wang, X., Feng, Z., Song, W., Feng, Z.W., Ouyang, Z., 2007. Effects of elevated ozone on biomass and yield of rice planted in open top chamber with revolving ozone distribution. Environmental Science 28, 170-175 (in Chinese) 